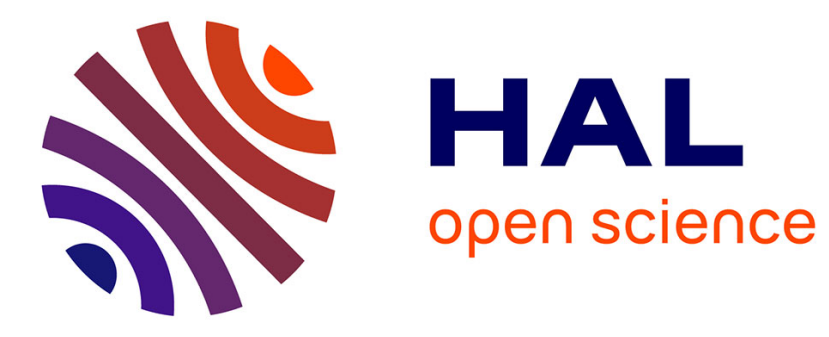

\title{
Multiple chemo-genetic interactions between a toxic metabolite and the ubiquitin pathway in yeast
}

\author{
Delphine Albrecht, Hans C Hürlimann, Johanna Ceschin, Christelle
}

Saint-Marc, Benoît Pinson, Bertrand Daignan-Fornier

\section{To cite this version:}

Delphine Albrecht, Hans C Hürlimann, Johanna Ceschin, Christelle Saint-Marc, Benoît Pinson, et al.. Multiple chemo-genetic interactions between a toxic metabolite and the ubiquitin pathway in yeast. Current Genetics, 2018, 64 (6), pp.1275-1286. 10.1007/s00294-018-0843-7 . hal-02346868

\section{HAL Id: hal-02346868 \\ https://hal.science/hal-02346868}

Submitted on 7 Nov 2019

HAL is a multi-disciplinary open access archive for the deposit and dissemination of scientific research documents, whether they are published or not. The documents may come from teaching and research institutions in France or abroad, or from public or private research centers.
L'archive ouverte pluridisciplinaire HAL, est destinée au dépôt et à la diffusion de documents scientifiques de niveau recherche, publiés ou non, émanant des établissements d'enseignement et de recherche français ou étrangers, des laboratoires publics ou privés. 
5 Delphine ALBRECHT ${ }^{1,2}$, Hans C. HURLIMANN ${ }^{1,2,3}$, Johanna CESCHIN ${ }^{1,2}$, Christelle SAINT-

6 MARC $^{1,2}$, Benoît PINSON ${ }^{1,2}$ and Bertrand DAIGNAN-FORNIER ${ }^{1,2 \#}$

7 From ${ }^{1}$ Université de Bordeaux and the ${ }^{2}$ Centre National de la Recherche Scientifique, IBGC UMR

8 5095, 1 rue Camille Saint-Saëns F-33077 Bordeaux 2 France.

$9{ }^{3}$ Present address: Institut für Biologie, Martin-Luther Universität, Universität Halle-Wittenberg, 10 Weinbergweg 10, 06120 Halle (Saale), Germany

11 \# To whom correspondence should be addressed: Institut de Biochimie et Génétique Cellulaires, 12 CNRS UMR 5095, 1 rue C. Saint-Saëns CS 61390 F-33077 Bordeaux France. Tel: +33-556-99913 001; Fax: +33-556-999-059; E-mail: b.daignan-fornier@ibgc.cnrs.fr

14 Running title: AICAR and the ubiquitin pathway 
Abstract

21 AICAR is the precursor of ZMP, a metabolite with anti-proliferative properties in yeast and human. We aim at understanding how AICAR (and its active form ZMP) affects essential cellular processes. In this work, we found that ZMP accumulation is synthetic lethal with a 


\section{INTRODUCTION}

ZMP, the monophosphate derivative of Amino-Imidazole CarboxAmide Ribonucleoside (AICAR), is a precursor of AMP in the purine de novo biosynthesis pathway (Fig. 1a) and as such is naturally present in cells at low concentrations (micro molar range, (Daignan-Fornier and Pinson, 2012; Hurlimann et al., 2011)). At higher concentrations, ZMP is a potent lowenergy mimetic which stimulates AMP-activated protein kinase (AMPK) by mimicking activation by AMP (Sullivan et al., 1994a; Sullivan et al., 1994b). In vivo, this AMPK activating effect was shown to increase endurance of sedentary mice (Narkar et al., 2008). At high concentrations, AICAR induces cell cycle arrest and/or apoptosis (Rattan et al., 2005). In vivo antitumor effects of AICAR have been reported in non-orthotopic mouse models (Guo et al., 2009; Liu et al., 2014; Rattan et al., 2005; Robert et al., 2009; Tang et al., 2011) and AICAR, also pharmacologically referred to as Acadesine, is considered as a potential antitumor agent. A Phase I/II study has been successfully conducted to determine the safety and tolerability of AICAR to treat patients with chronic lymphocytic leukemia (CLL) (Van Den Neste et al., 2013). We and others have shown that AICAR cytotoxicity was not affected in the absence of AMPK (Ceschin et al., 2014; Liu et al., 2014) indicating that AICAR has other important targets that could strongly contribute to its potential anti-tumor effects but could also cause unwanted side effects. In line with this remark, ZMP, the monophosphate derivative of AICAR is accumulated in several purine genetic diseases and could contribute to the poorly understood etiology of these diseases (Ceballos-Picot et al., 2015; Daignan-Fornier and Pinson, 2012). For all these reasons, understanding, how AICAR (and its active form ZMP) affects cellular processes and results in beneficial or an adverse effects, is crucial.

To identify cellular functions affected by AICAR, we took advantage of yeast genetics to isolate and characterize several yeast mutants showing higher sensitivity to AICAR (Albrecht et al., 2016; Ceschin et al., 2015; Ceschin et al., 2014). Of note, search for AICAR-sensitive mutants cannot easily be done at a genome wide scale since a specific and complex genetic set-up (ade16 ade17 ade8 his1) is required to reveal AICAR-sensitivity (Fig. 1a) (Ceschin et al., 2015; Hurlimann et al., 2011). Recently, we found that sensitivity to AICAR is connected with the ubiquitin pathway in yeast and mammals. In particular, AICAR treatment is synthetic lethal with loss of function of several histone-modifying enzymes in yeast and human cells (Albrecht et al., 2016). Indeed, in yeast cells, the deletion of BRE1, that catalyzes the ubiquitination of $\mathrm{H} 2 \mathrm{~B}(\mathrm{H} 2 \mathrm{Bub})$, results in a severe inhibition of growth under AICAR 
treatment. Accordingly, the non-ubiquitinable form of H2B, H2BK123R, was also found to be highly sensitive to AICAR. It is well known that H2Bub is a signal of transactivation for two methyltransferases, Dot 1 and Set1/COMPASS. We showed that a set1 mutant was exquisitely sensitive to AICAR, as was the non-methylable form of its targets H3K4. Remarkably, the knock-down of the corresponding orthologs, Rnf40 for Bre1, Ash21 and Mll4/KMT2D for COMPASS, were found to exacerbate AICAR sensitivity of human HCT116 cells (Albrecht et al., 2016).

Here, we show that a mutation in the UBAl gene encoding the yeast ubiquitin activating enzyme (E1) is synthetic lethal with AICAR treatment. This result prompted us to examine more systematically the connections between AICAR and the ubiquitin-pathway (Fig. 1b). We identified the ubiquitin pool as having a central role in AICAR sensitivity and established that mutants with reduced ubiquitin pools, such as $u b p 6$ or doal, are highly sensitive to the drug. Based on suppression patterns and additivity, these mutants were found to belong to a distinct branch of the ubiquitin-pathway which is required for yeast cells to cope with AICAR and acts in parallel to the Rad6/Bre1 branch identified previously (Albrecht et al., 2016). The complex chemo-genetic interactions between a metabolite and the ubiquitin pathway reported here, illustrate how poly-pharmacological effects can result in phenotypic synergy.

\section{Material and methods}

\section{Yeast media}

SD is a synthetic minimal medium containing $0.5 \%$ ammonium sulfate, $0.17 \%$ yeast nitrogen base without amino acids and ammonium sulfate (BD-Difco), 2\% glucose. SDcasaW is SD medium supplemented with $0.2 \%$ casamino acids (BD-Difco) and tryptophan $(0.2 \mathrm{mM})$. When indicated, adenine $(0.3 \mathrm{mM})$ and/or uracil $(0.3 \mathrm{mM})$ were added in SDcasaW medium resulting in media named SDcasaWA (+ adenine), SDcasaWU (+ uracil) and SDcasaWAU (+ adenine + uracil). SC medium was prepared as described (Sherman, 1986). SC complete medium is SC medium supplemented with adenine $(0.3 \mathrm{mM})$, uracil $(0.3 \mathrm{mM})$, histidine $(0.06$ $\mathrm{mM})$, leucine $(0.4 \mathrm{mM})$, lysine $(0.06 \mathrm{mM})$ and tryptophan $(0.2 \mathrm{mM})$.

\section{Strains and plasmids}

All yeast strains are listed in Table 1 and belong to, or are derived from, a set of disrupted 
107 strains isogenic to BY4741 or BY4742 purchased from Euroscarf. Multi-mutant strains were

obtained by crossing, sporulation and micromanipulation of meiosis progeny. For each cross, systematic tetrad analysis was done to verify correct segregation of the markers (mating type, auxotrophy, temperature sensitivity, PCR detection of KanMX4 knock-out...). The presence of the ubal-ol allele in the Y8033 strain used for gene dosage screening was verified by sequencing of the UBAI locus. All plasmids used in this study are listed in Table 2 and were obtained by PCR amplification on genomic DNA and cloning in indicated vectors. Cloning details are available upon request.

\section{Growth test}

Overnight pre-cultured yeast cells were re-suspended in sterile water at $3.10^{7}$ cells $/ \mathrm{ml}$ and submitted to $1 / 10$ serial dilutions. Drops $(5 \mu \mathrm{l})$ of each dilution were spotted on freshly prepared medium plates and were incubated at indicated temperature for $48-72 \mathrm{~h}$ before imaging.

\section{Isolation of multicopy suppressors of the uba1-o1 AICAR-sensitive phenotype}

Multicopy suppressors of the ade16 ade17 ade8 his1 ubal-ol AICAR-sensitive phenotype were obtained by transforming the Y8033 strain with a multicopy-plasmid library (PFL44L backbone, $2 \mu$ URA3; generous gift from F. Lacroute). Transformants selected on SDcasaWA medium at $25{ }^{\circ} \mathrm{C}$ were then replica-plated on the same medium containing or not AICAR (5 $\mathrm{mM}$ ) and plates were incubated for $1-3$ days at $33{ }^{\circ} \mathrm{C}$. As described in the Results section, we focused our attention on 5 clones containing ubiquitin-encoded genes: UBI4, RPLAOA and RPLAOB. Among those, the plasmid p4814 corresponded to a chromosome IX fragment (coordinates from $67814 \mathrm{bp}$ to $71209 \mathrm{bp}$ ) containing RPL4OA as the only entire gene. Three other plasmids contained fragments of chromosome XI with RPLAOB as the only entire common gene. Finally, the fifth plasmid presented a fragment of chromosome XII (coordinates from $63188 \mathrm{bp}$ to $67952 \mathrm{bp}$ ) containing 3 entire open reading frames (ORF): UBI4, ENT4 and YLL037w. Subcloning of the UBI4 ORF alone (P5504) in a YEplac195 plasmid (Gietz and Sugino, 1988) allowed us to show that this ORF was sufficient for suppression of the AICAR-sensitive phenotype.

\section{Western blotting}

Total protein extraction was performed by disruption of exponential growing cells with glassbeads in trichloro-acetic acid $5 \%$, as described in (Escusa et al., 2006). Protein extracts were 
separated by SDS-PAGE, transferred onto $0.45 \mu$ PVDF membrane and protein of interest were detected by western blotting using anti Act1 (generous gift from I. Sagot (Bordeaux, France), 1/100,000), anti-H2B (Active motif ; \#39237, 11/2,000) or anti Ubi (Abcam, \#ab19247 1/10,000). Blots Quantification was done with Image J (NIH).

\section{Results}

\section{Synthetic lethality of a uba1 mutation with ZMP accumulation can be rescued by ubiquitin} overexpression

Our previous report establishing a connection between sensitivity to AICAR and the ubiquitin pathway (Albrecht et al., 2016) prompted us to examine whether sensitivity to AICAR could be affected under conditions where the ubiquitin-pathway is dysfunctional. We started with the $U B A 1$ gene encoding the ubiquitin activating enzyme (E1) at the apex of the ubiquitin pathway, hence governing all the ubiquitin-dependent processes (McGrath et al., 1991). We asked whether accumulation of ZMP could lead to a synthetic phenotype when combined with a temperature sensitive allele (ubal-o1) of the UBA1 gene (Shimada et al., 2002). The ubalo1 mutant was mated to an ade16 ade17 double mutant which constitutively accumulates ZMP (Pinson et al., 2009) and meiosis of the resulting diploid was induced. Strikingly, in the meiotic progeny, no ade16 ade17 ubal-ol triple mutant could be obtained at permissive temperature unless rescued by a plasmid expressing the wild-type $U B A 1$ gene (Fig. 2a) thus revealing synthetic lethality between ade16 ade17 and ubal-ol. Importantly, this synthetic lethality could be totally abolished by ade8 and his 1 mutations (Fig. 2b) blocking ZMP synthesis upstream of Ade16 and Ade17 (Fig. 1a) and thus eliminating ZMP accumulation (Hurlimann et al., 2011). Finally, in the ubal-ol ade16 ade17 ade8 his1 mutant, the synthetic growth defect was recapitulated by addition of the ZMP-precursor AICAR at semi-permissive temperature $\left(33^{\circ} \mathrm{C}\right)$, a condition that did not affect growth of the ubal-ol ade16 ade17 ade 8 hisl mutant in the absence of AICAR (Fig. 2b). We conclude that the ubal-ol mutant is synthetic lethal with ZMP accumulation supplied by two different means, either endogenously from the purine pathway (Fig. 2a) or exogenously from the growth medium (Fig. 2b). Together these results reveal that partial loss of function of the ubiquitin-conjugating enzyme Uba1 is synthetic lethal with ZMP accumulation. Hence, the ubiquitin pathway appears critical for yeast cells to cope with ZMP. 
As a first step toward understanding how AICAR affects the ubiquitin pathway, we searched for gene-dosage suppressors that would restore growth of the ubal-ol ade16 ade17 ade 8 hisl mutant in the presence of AICAR. A genomic multicopy plasmid library was transformed in the ubal-ol ade16 ade17 ade8 his 1 mutant and a set of 37 clones showing improved capacity to grow in the presence of AICAR at $33^{\circ} \mathrm{C}$ were studied. Among them no plasmid carrying the $U B A 1$ gene was found suggesting that it was not present in the genomic library possibly because of the large size of the coding region $>3 \mathrm{~kb}$. Indeed, in a reconstitution experiment, the growth defect was fully suppressed by a plasmid expressing UBAl (not shown). Five plasmids contained either the ADE16 ( 3 clones) or the $A D E 17$ (2 clones) gene, thus restoring ATIC enzymatic activity and preventing ZMP accumulation. These plasmids were not further studied. Among the remaining clones, we only studied those carrying a single chromosome fragment and presenting a robust suppression phenotype after retransformation. Eleven such plasmids revealed DDP1 (1 clone), ECM21 (1 clone), RPLAOA (1 clone), RPL4OB (3 clones), UBI4 (1 clone) and URA6 (4 clones) as gene-dosage suppressors after individual subcloning (Fig. 2c). DDP1 encodes an inositol polyphosphate phosphatase, ECM21 encodes an arrestin and URA6 a uridylate kinase. The three remaining genes, UBI4, RPLAOA and RPLAOB, encode precursors of free ubiquitin (Finley et al., 1989; Finley et al., 1987) and were therefore directly related to $U B A l$ function as the ubiquitin-activating enzyme. We focused on those in the rest of the work. We conclude that overexpression of ubiquitin allows bypassing of AICAR sensitivity of the ubal-ol ade16 ade17 ade8 hisl mutant. This result suggested that the ubiquitin pool could play an important role in AICAR sensitivity in yeast. Importantly, the free-ubiquitin pool was significantly higher in the ubal-ol mutant than in the control strain (Fig. 2d, arrow) indicating that the exacerbated sensitivity of the ubal-ol mutant to AICAR is not due a lower pool of free-ubiquitin. In both wild-type and ubal-ol strains overexpression of UBI4 resulted in increased free-ubiquitin (Fig. 2d), though the amount of free ubiquitin was higher in the ubal-ol mutant possibly reflecting its defective utilization by the E1 mutant enzyme. In both strains, UBI4 overexpression strongly increased the signal of ubiquitylated proteins indicating that under physiological conditions ubiquitin synthesis limits the ubiquitylation process. Finally, we found no effect of AICAR treatment on the ubiquitin pool (Fig. 2d). From these results, we conclude that AICAR-sensitivity of the ubal-ol ade16 ade17 ade8 hisl mutant is not associated to a lower free-ubiquitin pool due to the mutation or to AICAR treatment, but rather to a defect in the ubiquitylation process that can be efficiently suppressed by overexpressing ubiquitin. We interpret these results as an indication that, in the 
ubal-ol ade16 ade17 ade8 his 1 mutant, a function aggravated by AICAR treatment can be rescued by ubiquitin overexpression.

\section{Mutants with reduced ubiquitin pools are highly sensitive to AICAR but do not recapitulate} the rad6/bre1 phenotypes

211 We next asked whether AICAR treatment itself could impose an enhanced demand for ubiquitin that would be exacerbated by the ubal mutation to a point leading to the observed AICAR-hypersensitivity of this mutant. Several yeast mutants such as, doal and ubp6, have constitutively reduced free-ubiquitin pools, due to defective ubiquitin recycling (Amerik et al., 2000; Johnson et al., 1995). The doal and ubp6 knock-out mutations were introduced in the ade16 ade17 ade8 hisl background allowing controlled accumulation of ZMP as a result of feeding with AICAR (Hurlimann et al., 2011). Both mutations were found to lower the ubiquitin pool (Fig. 3a) as previously reported (Amerik et al., 2000; Johnson et al., 1995) and to severely impair growth of yeast cells in the presence of AICAR (Fig. 3b). Importantly this growth defect could be robustly suppressed by overexpression of UBI4 (Fig. 3b), indicating that the low pool of ubiquitin was implicated in the exacerbated AICAR sensitivity of these mutants.

We then examined whether the chemo-genetic interaction between AICAR and the doal or ubp6 mutants was phenocopying the previously described synthetic lethality between ZMP and the rad6 or brel mutants (Albrecht et al., 2016). Indeed, in a previous work, we found that the ubiquitin conjugating enzyme Rad6 together with the ubiquitin ligase Bre1 were critical for yeast cells to grow in the presence of AICAR (Albrecht et al., 2016). This growth defect resulted from the lack of ubiquitylation of histone H2B in the absence of Rad6/Bre1 together with a cell cycle default associated to defective entry of the cyclin Cln3 in the nucleus due to AICAR treatment (Albrecht et al., 2016). Since free ubiquitin is present in limiting amounts in cells, changes in the ubiquitin pool directly affect ubiquitin modifications (Groothuis et al., 2006) (Fig. 2d) and accordingly the free ubiquitin pool was found to impact on histone ubiquitination in mammalian cells (Dantuma et al., 2006). Hence, we suspected that doal and $u b p 6$ mutants could directly affect $\mathrm{H} 2 \mathrm{~B}$ ubiquitination. Indeed, doal and ubp6 mutants showed a decreased ubiquitination of $\mathrm{H} 2 \mathrm{~B}$ that could be restored by UBI4 overexpression (Fig. 3c). These results suggested that low-ubiquitin mutants could be sensitive to AICAR in part because of the reduced ubiquitylation of $\mathrm{H} 2 \mathrm{~B}$ that could mimic the 
bre1 or rad6 phenotype. This assumption was directly assessed by genetic means, i.e. by

comparing their suppression pattern. The rationale here was that if doal and $u b p 6$ mutants are sensitive to AICAR because they mimic rad6 or bre1, they should be suppressed by the same suppressors. As previously reported (Albrecht et al., 2016), CLN3 overexpression could efficiently suppress the AICAR growth-defect of the bre1 mutant (Fig. 3b), however it had little or no effect on $u b p 6$ or doal mutations (Fig. 3b). We conclude that part of the effects of ubp6 or doal mutations are likely due to their lower ability to ubiquitylate $\mathrm{H} 2 \mathrm{~B}$, but that a remaining part of their effect is independent of Rad6/Bre1 and can be suppressed by increasing cellular ubiquitin (Fig. 3B). These results suggested that another effector in the ubiquitin pathway was involved. We then aimed at identifying this effector.

\section{Genetic analysis reveals new E2 and E3 AICAR-sensitive mutants}

Ubiquitin once activated by Uba1 is conveyed to ubiquitin-conjugating enzymes (E2s), which in turn, with or without the help of specific ubiquitin ligases (E3s), transfer the ubiquitin moiety to the target proteins (Fig. 1b). In yeast there are 11 E2s and dozens of E3s (Finley et al., 2012). To further explore how AICAR affects the ubiquitylation pathway downstream of Uba1 (E1), we started with a systematic genetic analysis of the ubiquitin conjugating enzymes (E2s). Among the eleven yeast E2s, nine are encoded by non-essential genes (Finley et al., 2012). The corresponding knock-out mutations were combined with the ade16 ade17 ade8 his1 mutations allowing ZMP accumulation in yeast when yeast cells are fed with AICAR (Hurlimann et al., 2011). While most E2 mutations did not affect the sensitivity to AICAR accumulation (Fig. 4a), the rad6 (ubc2) knock-out strongly altered growth in the presence of AICAR (Fig. 4a), thus confirming our previous report (Albrecht et al., 2016). In addition, $u b c 4$ was also sensitive to AICAR accumulation (Fig. 4a) although to a lesser extent. Ubc4 is known to be involved in protein degradation. In particular, Ubc4 coupled with Not4 polyubiquitinates the H3K4 demethylase, Jhd2, leading to its degradation (Mersman et al., 2009). Thus, Jhd2 stabilization in the $u b c 4$ mutant would lead to lower H3K4 methylation (Mersman et al., 2009) hence phenocopying a defect in H3K4 methylation by Set1. Since Set1 methylation of H3K4 is dependent on H2B ubiquitylation by Rad6/Bre1 (Nakanishi et al., 2009) a defective Ubc4 should mimic the rad6/brel defect and should show the same suppression pattern. Indeed, the $u b c 4$ mutant growth defect in the presence of AICAR was robustly suppressed by $C L N 3$ overexpression but not by UBI4 (Fig. 4b), hence phenocopying 
a bre1 mutant (Fig. 3d). This result thus phenotypically positioned the $u b c 4$ mutant in the

"rad6/bre1/set1 pathway".

We then examined the effect of a defect in the two remaining essential E2s, Ubc1 and Ubc3/Cdc34, on AICAR sensitivity. We found that, in the $\mathrm{S} 288 \mathrm{c}$ background, $U B C 1$ is essential for germination but not for vegetative growth and we could thus construct a viable ade16 ade17 ade8 his1 ubcl quintuple mutant. Clearly, ubcl knock-out did not affect growth in the presence of AICAR (Fig. 4c) (compared to setl shown here as an AICAR-sensitive control). For $c d c 34$, AICAR-sensitivity was assayed on a temperature sensitive allele $c d c 34-2$ (Liu et al., 1995) at semi-permissive temperature. The $c d c 34-2$ mutant was highly sensitive to endogenous ZMP accumulation (Fig. 4d) or AICAR as an exogenous source of ZMP (Fig. 4e). Cdc34 catalyzes substrate ubiquitination via the Skp1-Cullin-F-box (SCF) ubiquitin protein ligase complex in which the F-box proteins function as substrate-specific adaptors (Feldman et al., 1997; Goebl et al., 1988; Skowyra et al., 1997). Cdc4 is one of these F-box proteins and we asked whether it would be required for growth under conditions leading to ZMP accumulation. The $c d c 4-3$ mutation was highly sensitive to ZMP accumulation whether it was from an internal source (ade16 ade17 background; Fig. 4f) or upon AICAR feeding (ade16 ade17 ade8 his 1 background; Fig. 4g). We conclude that Cdc34 and Cdc4 define a new ubiquitin sub-pathway required for cells to cope with AICAR.

Suppression and additivity patterns unveil complex interactions between ZMP and the ubiquitin pathway

Phenotypic suppression of the newly identified $c d c 34$ and $c d c 4$ mutants by increased gene dosage of CLN3 or UBI4 was evaluated. The AICAR sensitivity of the $c d c 34-2$ mutant was suppressed by overexpression of UBI4 but not by CLN3 (Fig. 5a). By contrast, $c d c 4-3$ was slightly suppressed by CLN3 but not by UBI4 increased gene dosage (Fig. 5b-c). Finally, CLB5 a known dosage suppressor of $c d c 4$ (Cui et al., 2002) indeed suppressed the high sensitivity to AICAR of the corresponding $c d c 4-3$ temperature sensitive mutants (Fig. 5c) but also that of a $c d c 34-2$ mutant (Fig. 5d). Still, CLB5 overexpression had no effect on AICARsensitivity of the bre1, set1, doal, ubp6 and ubal-ol mutants (Fig. 5e-i). Thus based on genedosage suppression patterns, we can distinguish the various mutants of the ubiquitin pathway leading to AICAR sensitivity (Fig. 6). A simple assumption derived from this model is that mutations affecting the distinct "branches" should have additive effects. This was assayed by 
constructing a bre1 ubp6 strain capable of accumulating ZMP upon AICAR feeding (ade16 ade17 ade8 his 1 background). We found that the bre1 ubp6 mutant was much more sensitive to AICAR than a brel or an ubp6 strain alone at low AICAR concentration (2 mM, Fig. 7a). This additivity indicates that the chemo-genetic interaction of these two mutants with AICAR involves different functions. Accordingly, UBI4 overexpression could still suppress a part, but not all, of the sensitivity to AICAR of the bre1 ubp6 strain, resulting in a level of AICARsensitivity equivalent to that of a single brel mutant (Fig. 7a). Additivity was also found for the setl and doal mutations (Fig. 7b) confirming the idea that these mutations result in AICAR sensitivity through different means as deduced from their suppression pattern (Fig. 6). Finally, co-overexpression of CLN3 and UBI4 in the ubal-ol mutant showed an additive suppression effect (Fig. 7c) indicating that the ubal mutation affects both downstream branches, as expected for a mutation affecting the enzyme which is at the apex of the ubiquitin pathway. Interestingly, the ubal-ol mutant exhibited a strong defect in $\mathrm{H} 2 \mathrm{~B}$ ubiquitination at semi-permissive temperature and this could be restored by UBI4 overexpression (Fig. 7d). Hence, while UBI4 overexpression restored H2B ubiquitylation, it only partially suppressed the ubal-ol growth phenotype (Fig. 7c) suggesting that the Rad6/Bre1 branch might affect one or several other targets than H2B that would be suppressed by $C L N 3$ overexpression but not or only partially by $U B I 4$ overexpression. We conclude that ZMP accumulation results in multiple chemo-genetic interactions with the ubiquitin pathway in yeast, thus illustrating the complexity of drug action and the helpfulness of genetics to address it.

\section{DISCUSSION}

In a previous work we identified histone ubiquitylation mutants as synthetic lethal with AICAR treatment (Albrecht et al., 2016). Here we further uncovered phenotypic interactions between AICAR/ZMP and the ubiquitin pathway and identified several new mutants (ubal, $u b c 4, c d c 34, c d c 4, u b p 6$ and doal) showing exacerbated sensitivity to AICAR. Differential patterns of gene dosage suppression as well as phenotypic additivity revealed that these mutants affect distinct branches, hence suggesting that AICAR interferes with one or several functions particularly required when the ubiquitin pathway is impaired. Among the mutants studied here and in our previous study, uba-ol was the only one resulting in synthetic lethality with the ade16 ade17 mutations leading to constitutive ZMP accumulation as revealed by our 
334 inability to recover viable spores. This pronounced sensitivity could reflect the fact that Uba1

(E1) is at the apex of the ubiquitin pathway and therefore conditions all downstream ubiquitin reactions. Among the 11 ubiquitin conjugating enzyme (E2) mutants, three (rad6, ubc4 and $c d c 34)$ were affected by the drug hence revealing the major pathways downstream of Uba1 that are required for yeast cells to resist AICAR. Following-up on Cdc34, we could identify the Cdc4 ubiquitin ligase (E3) as required for AICAR tolerance.

340 Why is AICAR toxic for ubiquitin pathway mutants? We have shown in this work that the abundance of ubiquitin itself is an important factor in the drug toxicity though we demonstrated that AICAR does not directly affect it. Clearly in the case of doal and ubp6 it is the low ubiquitin pool that is responsible for the exacerbated toxicity of AICAR. It is likely that more than one function is involved in the phenotype and indeed these mutants were not efficiently suppressed by overexpression of neither CLN3 nor CLB5. For $c d c 34$ and $c d c 4$, both mutants were suppressed by CLB5 overexpression, while this was not the case for the other AICAR-sensitive mutants, suggesting that a negative effector stabilized in these mutants could be displaced by CLB5 overexpression. It remains to be established whether the multiple connections, between AICAR and the ubiquitin pathway, revealed here, are more than serendipitous i.e. whether there is a common target that when affected by ZMP results in synthetic toxicity with the various ubiquitin mutants. The fact, that up to now, we identified no common gene dosage suppressor to the various mutants, does not support this hypothesis. However, Uba1 was found among ZMP-binders by affinity chromatography (our unpublished results) and could therefore be a direct and central target. In any case, the strong connections between AICAR and the ubiquitin pathway could be highly relevant to understand why AICAR selectively inhibits proliferation of aneuploid cells (Tang et al., 2011). Indeed, aneuploidy is known to result in proteotoxicity (Donnelly and Storchova, 2015; Santaguida and Amon, 2015) and as such could impose a strong demand on the ubiquitin pathway. This work thus provides a lead for further work on AICAR selective effects on aneuploid cells. 
References

361

4362

5363

6364

7365

8366

10367

11368

12369

13

Albrecht, D., J. Ceschin, J. Dompierre, F. Gueniot, B. Pinson, and B. Daignan-Fornier. 2016. Chemo-Genetic Interactions Between Histone Modification and the Antiproliferation Drug AICAR Are Conserved in Yeast and Humans. Genetics. 204:1447-1460.

Amerik, A.Y., S.J. Li, and M. Hochstrasser. 2000. Analysis of the deubiquitinating enzymes of the yeast Saccharomyces cerevisiae. Biological chemistry. 381:981-992.

Bonneaud, N., O. Ozier-Kalogeropoulos, G.Y. Li, M. Labouesse, L. Minvielle-Sebastia, and F. Lacroute. 1991. A family of low and high copy replicative, integrative and singlestranded S. cerevisiae/E. coli shuttle vectors. Yeast. 7:609-615.

Ceballos-Picot, I., A. Le Dantec, A. Brassier, J.P. Jais, M. Ledroit, J. Cahu, H.K. Ea, B. Daignan-Fornier, and B. Pinson. 2015. New biomarkers for early diagnosis of LeschNyhan disease revealed by metabolic analysis on a large cohort of patients. Orphanet journal of rare diseases. 10:7.

Ceschin, J., H.C. Hurlimann, C. Saint-Marc, D. Albrecht, T. Violo, M. Moenner, B. DaignanFornier, and B. Pinson. 2015. Disruption of Nucleotide Homeostasis by the Antiproliferative Drug 5-Aminoimidazole-4-carboxamide-1-beta-d-ribofuranoside Monophosphate (AICAR). J Biol Chem. 290:23947-23959.

Ceschin, J., C. Saint-Marc, J. Laporte, A. Labriet, C. Philippe, M. Moenner, B. DaignanFornier, and B. Pinson. 2014. Identification of yeast and human 5-aminoimidazole-4carboxamide-1-beta-d-ribofuranoside (AICAr) transporters. J Biol Chem. 289:1684416854.

Cui, Z., J. Horecka, and Y. Jigami. 2002. Cdc4 is involved in the transcriptional control of OCH1, a gene encoding alpha-1,6-mannosyltransferase in Saccharomyces cerevisiae. Yeast. 19:69-77.

Daignan-Fornier, B., and B. Pinson. 2012. 5-Aminoimidazole-4-carboxamide-1-beta-Dribofuranosyl 5'-Monophosphate (AICAR), a Highly Conserved Purine Intermediate with Multiple Effects. Metabolites. 2:292-302.

Dantuma, N.P., T.A. Groothuis, F.A. Salomons, and J. Neefjes. 2006. A dynamic ubiquitin equilibrium couples proteasomal activity to chromatin remodeling. J Cell Biol. 173:19-26.

Donnelly, N., and Z. Storchova. 2015. Causes and consequences of protein folding stress in aneuploid cells. Cell Cycle. 14:495-501.

Escusa, S., J. Camblong, J.M. Galan, B. Pinson, and B. Daignan-Fornier. 2006. Proteasomeand SCF-dependent degradation of yeast adenine deaminase upon transition from proliferation to quiescence requires a new F-box protein named Saf1p. Mol Microbiol. 60:1014-1025.

Feldman, R.M., C.C. Correll, K.B. Kaplan, and R.J. Deshaies. 1997. A complex of Cdc4p, Skp1p, and Cdc53p/cullin catalyzes ubiquitination of the phosphorylated CDK inhibitor Sic1p. Cell. 91:221-230.

Finley, D., B. Bartel, and A. Varshavsky. 1989. The tails of ubiquitin precursors are ribosomal proteins whose fusion to ubiquitin facilitates ribosome biogenesis. Nature. 338:394-401.

Finley, D., E. Ozkaynak, and A. Varshavsky. 1987. The yeast polyubiquitin gene is essential for resistance to high temperatures, starvation, and other stresses. Cell. 48:1035-1046.

Finley, D., H.D. Ulrich, T. Sommer, and P. Kaiser. 2012. The ubiquitin-proteasome system of Saccharomyces cerevisiae. Genetics. 192:319-360.

Gari, E., L. Piedrafita, M. Aldea, and E. Herrero. 1997. A set of vectors with a tetracyclineregulatable promoter system for modulated gene expression in Saccharomyces cerevisiae. Yeast. 13:837-848. 
Gietz, R.D., and A. Sugino. 1988. New yeast-Escherichia coli shuttle vectors constructed with in vitro mutagenized yeast genes lacking six-base pair restriction sites. Gene. 74:527534.

Goebl, M.G., J. Yochem, S. Jentsch, J.P. McGrath, A. Varshavsky, and B. Byers. 1988. The yeast cell cycle gene CDC34 encodes a ubiquitin-conjugating enzyme. Science. 241:1331-1335.

Groothuis, T.A., N.P. Dantuma, J. Neefjes, and F.A. Salomons. 2006. Ubiquitin crosstalk connecting cellular processes. Cell Div. 1:21.

Guo, D., I.J. Hildebrandt, R.M. Prins, H. Soto, M.M. Mazzotta, J. Dang, J. Czernin, J.Y. Shyy, A.D. Watson, M. Phelps, C.G. Radu, T.F. Cloughesy, and P.S. Mischel. 2009. The AMPK agonist AICAR inhibits the growth of EGFRvIII-expressing glioblastomas by inhibiting lipogenesis. Proc Natl Acad Sci U S A. 106:12932-12937.

Hurlimann, H.C., B. Laloo, B. Simon-Kayser, C. Saint-Marc, F. Coulpier, S. Lemoine, B. Daignan-Fornier, and B. Pinson. 2011. Physiological and toxic effects of purine intermediate 5-amino-4-imidazolecarboxamide ribonucleotide (AICAR) in yeast. $J$ Biol Chem. 286:30994-31002.

Johnson, E.S., P.C. Ma, I.M. Ota, and A. Varshavsky. 1995. A proteolytic pathway that recognizes ubiquitin as a degradation signal. J Biol Chem. 270:17442-17456.

Li, Z., F.J. Vizeacoumar, S. Bahr, J. Li, J. Warringer, F.S. Vizeacoumar, R. Min, B. Vandersluis, J. Bellay, M. Devit, J.A. Fleming, A. Stephens, J. Haase, Z.Y. Lin, A. Baryshnikova, H. Lu, Z. Yan, K. Jin, S. Barker, A. Datti, G. Giaever, C. Nislow, C. Bulawa, C.L. Myers, M. Costanzo, A.C. Gingras, Z. Zhang, A. Blomberg, K. Bloom, B. Andrews, and C. Boone. 2011. Systematic exploration of essential yeast gene function with temperature-sensitive mutants. Nat Biotechnol. 29:361-367.

Liu, X., R.R. Chhipa, S. Pooya, M. Wortman, S. Yachyshin, L.M. Chow, A. Kumar, X. Zhou, Y. Sun, B. Quinn, C. McPherson, R.E. Warnick, A. Kendler, S. Giri, J. Poels, K. Norga, B. Viollet, G.A. Grabowski, and B. Dasgupta. 2014. Discrete mechanisms of mTOR and cell cycle regulation by AMPK agonists independent of AMPK. Proc Natl Acad Sci U S A. 111:E435-444.

Liu, Y., N. Mathias, C.N. Steussy, and M.G. Goebl. 1995. Intragenic suppression among CDC34 (UBC3) mutations defines a class of ubiquitin-conjugating catalytic domains. Mol Cell Biol. 15:5635-5644.

McGrath, J.P., S. Jentsch, and A. Varshavsky. 1991. UBA 1: an essential yeast gene encoding ubiquitin-activating enzyme. EMBO J. 10:227-236.

Mersman, D.P., H.N. Du, I.M. Fingerman, P.F. South, and S.D. Briggs. 2009. Polyubiquitination of the demethylase Jhd2 controls histone methylation and gene expression. Genes Dev. 23:951-962.

Nakanishi, S., J.S. Lee, K.E. Gardner, J.M. Gardner, Y.H. Takahashi, M.B. Chandrasekharan, Z.W. Sun, M.A. Osley, B.D. Strahl, S.L. Jaspersen, and A. Shilatifard. 2009. Histone H2BK123 monoubiquitination is the critical determinant for H3K4 and H3K79 trimethylation by COMPASS and Dot1. J Cell Biol. 186:371-377.

Narkar, V.A., M. Downes, R.T. Yu, E. Embler, Y.X. Wang, E. Banayo, M.M. Mihaylova, M.C. Nelson, Y. Zou, H. Juguilon, H. Kang, R.J. Shaw, and R.M. Evans. 2008. AMPK and PPARdelta agonists are exercise mimetics. Cell. 134:405-415.

Pinson, B., S. Vaur, I. Sagot, F. Coulpier, S. Lemoine, and B. Daignan-Fornier. 2009. Metabolic intermediates selectively stimulate transcription factor interaction and modulate phosphate and purine pathways. Genes Dev. 23:1399-1407.

Rattan, R., S. Giri, A.K. Singh, and I. Singh. 2005. 5-Aminoimidazole-4-carboxamide-1-betaD-ribofuranoside inhibits cancer cell proliferation in vitro and in vivo via AMPactivated protein kinase. J Biol Chem. 280:39582-39593. 
Robert, G., I. Ben Sahra, A. Puissant, P. Colosetti, N. Belhacene, P. Gounon, P. Hofman, F. Bost, J.P. Cassuto, and P. Auberger. 2009. Acadesine kills chronic myelogenous leukemia (CML) cells through PKC-dependent induction of autophagic cell death. PLoS One. 4:e7889.

Santaguida, S., and A. Amon. 2015. Short- and long-term effects of chromosome missegregation and aneuploidy. Nat Rev Mol Cell Biol. 16:473-485.

Sherman, F., Fink, G. R., Hicks, J. B. 1986. Methods in yeast genetics. Cold Spring Harbor, New York.

Shimada, K., P. Pasero, and S.M. Gasser. 2002. ORC and the intra-S-phase checkpoint: a threshold regulates Rad53p activation in S phase. Genes Dev. 16:3236-3252.

Skowyra, D., K.L. Craig, M. Tyers, S.J. Elledge, and J.W. Harper. 1997. F-box proteins are receptors that recruit phosphorylated substrates to the SCF ubiquitin-ligase complex. Cell. 91:209-219.

Sullivan, J.E., K.J. Brocklehurst, A.E. Marley, F. Carey, D. Carling, and R.K. Beri. 1994a. Inhibition of lipolysis and lipogenesis in isolated rat adipocytes with AICAR, a cellpermeable activator of AMP-activated protein kinase. FEBS Lett. 353:33-36.

Sullivan, J.E., F. Carey, D. Carling, and R.K. Beri. 1994b. Characterisation of 5'-AMPactivated protein kinase in human liver using specific peptide substrates and the effects of 5'-AMP analogues on enzyme activity. Biochem Biophys Res Commun. 200:1551-1556.

Tang, Y.C., B.R. Williams, J.J. Siegel, and A. Amon. 2011. Identification of aneuploidyselective antiproliferation compounds. Cell. 144:499-512.

Van Den Neste, E., B. Cazin, A. Janssens, E. Gonzalez-Barca, M.J. Terol, V. Levy, J. Perez de Oteyza, P. Zachee, A. Saunders, M. de Frias, and C. Campas. 2013. Acadesine for patients with relapsed/refractory chronic lymphocytic leukemia (CLL): a multicenter phase I/II study. Cancer chemotherapy and pharmacology. 71:581-591. 
Tables

Table 1 Yeast strains used in this study

\begin{tabular}{|c|c|c|}
\hline Strain & Genotype & References \\
\hline BY4741 & MATa his $3 \Delta 1$ leu $2 \Delta 0$ met $15 \Delta 0$ ura $3 \Delta 0$ & Euroscarf \\
\hline BY4742 & $M A T \alpha$ his $3 \Delta 1$ leu $2 \Delta 0$ lys $2 \Delta 0$ ura $3 \Delta 0$ & Euroscarf \\
\hline Y1093 & MATa his $3 \Delta 1$ leu $2 \Delta 0$ ura $3 \Delta 0$ ade $16::$ KanMX4 ade17::KanMX4 & $\begin{array}{l}\text { (Hurlimann } \\
\text { et al., } \\
\text { 2011) }\end{array}$ \\
\hline Y1162 & 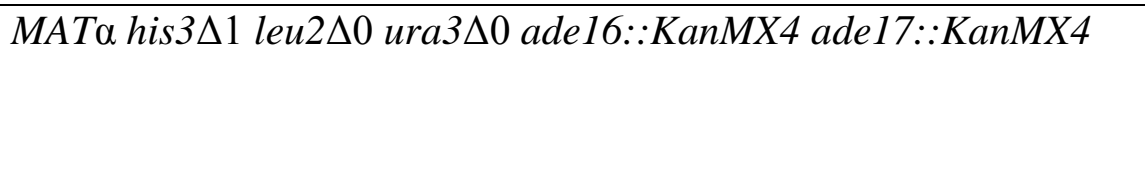 & $\begin{array}{l}\text { (Hurlimann } \\
\text { et al., } \\
\text { 2011) }\end{array}$ \\
\hline Y2950 & $\begin{array}{l}\text { MATa his } 3 \Delta 1 \text { leu } 2 \Delta 0 \text { ura3 } \Delta 0 \text { ade8::KanMX4 ade16::KanMX4 } \\
\text { ade17::KanMX4 his1::KanMX4 }\end{array}$ & $\begin{array}{l}\text { (Pinson et } \\
\text { al., 2009) }\end{array}$ \\
\hline Y3273 & MATa his $3 \Delta 1$ leu $2 \Delta 0$ met $15 \Delta 0$ ura $3 \Delta 0$ cdc4-3 & $\begin{array}{l}\text { (Li et al., } \\
2011)\end{array}$ \\
\hline Y3275 & MATa his $3 \Delta 1$ leu $2 \Delta 0$ met $15 \Delta 0$ ura3 $\Delta 0$ cdc34-2 & $\begin{array}{l}\text { (Li et al., } \\
2011)\end{array}$ \\
\hline Y6853 & MATa his $3 \Delta 1$ leu $2 \Delta 0$ met15 0 ura3 $\Delta 0$ ubal-ol & $\begin{array}{l}\text { (Li et al., } \\
2011)\end{array}$ \\
\hline Y6987 & MAT $\alpha$ his $3 \Delta 1$ leu $2 \Delta 0$ ura3 $\Delta 0$ ubal-ol & This study \\
\hline Y7070 & MATa his $3 \Delta 1$ leu $2 \Delta 0$ ura3 $\Delta 0$ ade 17::KanMX4 ubal-o1 & This study \\
\hline Y7071 & MAT $\alpha$ his $3 \Delta 1$ leu $2 \Delta 0$ ura3 $\Delta 0$ ade16::KanMX4 ubal-ol & This study \\
\hline Y7117 & $\begin{array}{l}\text { MATa his } 3 \Delta 1 \text { leu } 2 \Delta 0 \text { ura3 } \Delta 0 \text { ade16::KanMX4 ade17::KanMX4 } \\
\text { ubal-o1 [ptet-UBA1] }\end{array}$ & This study \\
\hline Y8033 & $\begin{array}{l}\text { MATa his } 3 \Delta 1 \text { leu2 } \Delta 0 \text { ura3 } \Delta 0 \text { ade }:: K a n M X 4 \text { ade16::KanMX4 } \\
\text { ade17::KanMX4 his1::KanMX4 ubal-o1 [ptet-empty, CEN LEU2] }\end{array}$ & This study \\
\hline Y8385 & $\begin{array}{l}\text { MATa his } 3 \Delta 1 \text { leu2 } \Delta 0 \text { ura3 } \Delta 0 \text { ade } 16:: \text { KanMX4 ade } 17:: \text { KanMX4 } \\
\text { cdc4-3 }\end{array}$ & This study \\
\hline Y8406 & $\begin{array}{l}\text { MATa his } 3 \Delta 1 \text { leu } 2 \Delta 0 \text { ura } 3 \Delta 0 \text { ade } 16:: \text { KanMX4 ade17::KanMX4 } \\
\text { cdc34-2 }\end{array}$ & This study \\
\hline Y8675 & 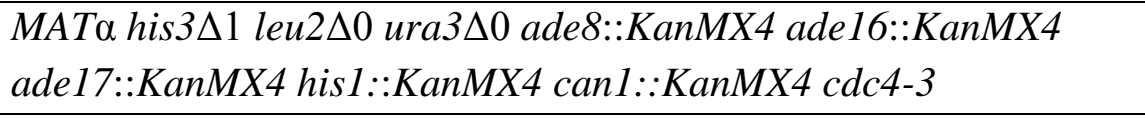 & This study \\
\hline Y8679 & $\begin{array}{l}\text { MATa his } 3 \Delta 1 \text { leu } 2 \Delta 0 \text { ura3 } \Delta 0 \text { ade }:: K a n M X 4 \text { ade } 16:: \text { KanMX4 } \\
\text { ade17::KanMX4 his } 1:: \text { KanMX4 cdc34-2 }\end{array}$ & This study \\
\hline Y9168 & $\begin{array}{l}\text { MATa his } 3 \Delta 1 \text { leu } 2 \Delta 0 \text { met } 15 \Delta 0 \text { ura3 } \Delta 0 \text { ade } 8:: K a n M X 4 \\
\text { ade16::KanMX4 ade17::KanMX4 his } 1:: \text { KanMX4 set } 1:: \text { KanMX4 }\end{array}$ & $\begin{array}{l}\text { (Albrecht } \\
\text { et al., } \\
\text { 2016) }\end{array}$ \\
\hline Y9217 & 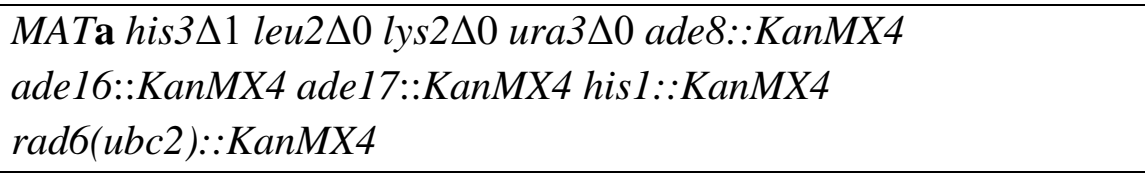 & This study \\
\hline Y9516 & MATa his $3 \Delta 1$ leu $2 \Delta 0$ ura $3 \Delta 0$ ade $8::$ KanMX4 ade $16::$ KanMX4 & This study \\
\hline
\end{tabular}




\begin{tabular}{|c|c|c|}
\hline & ade17::KanMX4 his1::KanMX4 bre1::kanMX4 & \\
\hline Y9915 & 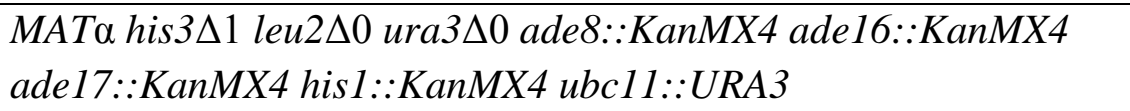 & This study \\
\hline Y9923 & $\begin{array}{l}\text { MATa his } 3 \Delta 1 \text { leu } 2 \Delta 0 \text { lys } 2 \Delta 0 \text { ura3 } \Delta 0 \text { ade } 8:: K a n M X 4 \\
\text { ade16::KanMX4 ade } 17:: \text { KanMX4 his1::KanMX4 ubc5::KanMX4 }\end{array}$ & This study \\
\hline Y9925 & 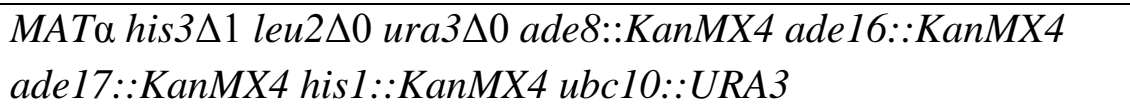 & This study \\
\hline Y9929 & 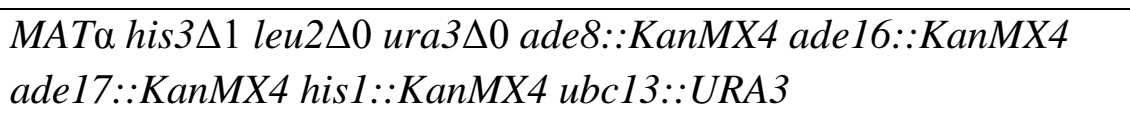 & This study \\
\hline Y9931 & $\begin{array}{l}\text { MATa his } 3 \Delta 1 \text { leu2 } \Delta 0 \text { ura3 } \Delta 0 \text { ade } 8: \text { KanMX4 ade } 16:: \text { KanMX4 } \\
\text { ade17::KanMX4 his1::KanMX4 ubc8::URA3 }\end{array}$ & This study \\
\hline Y9964 & $\begin{array}{l}\text { MATa his } 3 \Delta 1 \text { leu } 2 \Delta 0 \text { ura3 } \Delta 0 \text { ade }:: \text { KanMX4 ade } 16:: \text { KanMX4 } \\
\text { ade17::KanMX4 his } 1:: \text { KanMX4 ubc7::KanMX4 }\end{array}$ & This study \\
\hline Y10034 & $\begin{array}{l}\text { MATa his } 3 \Delta 1 \text { leu2 } \Delta 0 \text { lys } 2 \Delta 0 \text { ura } 3 \Delta 0 \text { ade }:: \text { KanMX4 } \\
\text { ade16::KanMX4 ade17::KanMX4 his1::KanMX4 ubc6::LEU2 }\end{array}$ & This study \\
\hline Y10072 & $\begin{array}{l}\text { MATa his } 3 \Delta 1 \text { leu } 2 \Delta 0 \text { lys } 2 \Delta 0 \text { ura3 } \Delta 0 \text { ade8::KanMX4 } \\
\text { ade16::KanMX4 ade } 17:: \text { KanMX4 his1::KanMX4 ubc4::KanMX4 }\end{array}$ & This study \\
\hline Y10296 & $\begin{array}{l}\text { MATa his } 3 \Delta 1 \text { leu2 } \Delta 0 \text { lys } 2 \Delta 0 \text { met } 15 \Delta 0 \text { ura3 } \Delta 0 \text { ade }:: \text { KanMX4 } \\
\text { ade16::KanMX4 ade17::KanMX4 his1::KanMX4 ubp6::KanMX4 }\end{array}$ & This study \\
\hline Y10524 & 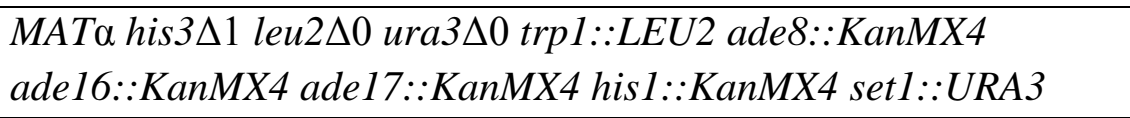 & This study \\
\hline Y10696 & $\begin{array}{l}\text { MATa his } 3 \Delta 1 \text { leu } 2 \Delta 0 \text { ura } 3 \Delta 0 \text { ade }:: \text { KanMX4 ade16::KanMX4 } \\
\text { ade17::KanMX4 his1::KanMX4 doa1 }:: \text { KanMX4 }\end{array}$ & This study \\
\hline Y10757 & $\begin{array}{l}\text { MATa his } 3 \Delta 1 \text { leu2 } \Delta 0 \text { lys } 2 \Delta 0 \text { ura3 } \Delta 0 \text { ade }:: \text { KanMX4 } \\
\text { ade16::KanMX4 ade } 17:: \text { KanMX4 his1::KanMX4 bre1::KanMX4 } \\
\text { ubp6::KanMX4 }\end{array}$ & This study \\
\hline Y10817 & MAT $\alpha$ his $3 \Delta 1$ leu $2 \Delta 0$ met $15 \Delta 0$ ura3 $\Delta 0$ ubcl::KanMX4 & This study \\
\hline Y10840 & 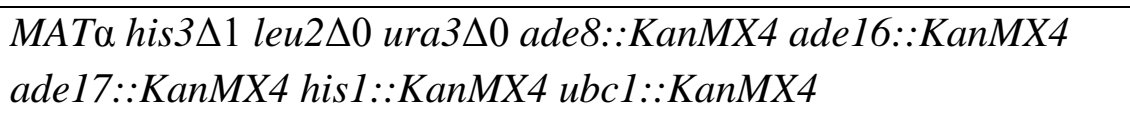 & This study \\
\hline Y11352 & $\begin{array}{l}\text { MATa his } 3 \Delta 1 \text { leu } 2 \Delta 0 \text { ura3 } \Delta 0 \text { ade }:: \text { KanMX4 ade16::KanMX4 } \\
\text { ade17::KanMX4 his } 1:: \text { KanMX4 uba1-o1 }\end{array}$ & This study \\
\hline Y11389 & $\begin{array}{l}\text { MATa his } 3 \Delta 1 \text { leu } 2 \Delta 0 \text { trp } 1:: L E U 2 \text { ura3 } \triangle 0 \text { ade }:: \text { KanMX4 } \\
\text { ade16::KanMX4 ade } 17:: \text { KanMX4 his } 1:: \text { KanMX4 doal }:: \text { KanMX4 } \\
\text { set } 1:: U R A 3\end{array}$ & This study \\
\hline
\end{tabular}


Table 2 Plasmid used in this study

\begin{tabular}{|c|c|c|c|}
\hline Plasmid & Backbone & characteristics & Sources \\
\hline pCM189 & pCM189 & CEN ARS URA3 tet-OFF promoter & $\begin{array}{l}\text { (Gari et } \\
\text { al., 1997) }\end{array}$ \\
\hline pFL44L & pFL44L & 2 micron $U R A 3$ & $\begin{array}{l}\text { (Bonneaud } \\
\text { et al., } \\
\text { 1991) }\end{array}$ \\
\hline YCpLac111 & YCplac111 & CEN ARS LEU2 & $\begin{array}{l}\text { (Gietz and } \\
\text { Sugino, } \\
\text { 1988) }\end{array}$ \\
\hline YEpLac 181 & YEpLac 181 & 2 micron $L E U 2$ & $\begin{array}{l}\text { (Gietz and } \\
\text { Sugino, } \\
\text { 1988) }\end{array}$ \\
\hline YEpLac 195 & YEpLac 195 & 2 micron $U R A 3$ & $\begin{array}{l}\text { (Gietz and } \\
\text { Sugino, } \\
1988 \text { ) }\end{array}$ \\
\hline $\mathrm{p} 4515$ & pCM189 & CEN ARS URA3 tet-OFF promoter-UBA1 & This study \\
\hline $\mathrm{p} 4742$ & YEpLac 195 & CLN3 2 micron $U R A 3$ & $\begin{array}{l}\text { (Albrecht } \\
\text { et al., } \\
\text { 2016) }\end{array}$ \\
\hline $\mathrm{p} 4807$ & pFL44L & 2 micron $U R A 3$ RPLAOB PTR2 & This study \\
\hline $\mathrm{p} 4814$ & pFL44L & 2 micron $U R A 3$ RPLAOA & This study \\
\hline $\mathrm{p} 4859$ & YEpLac 195 & 2 micron $U R A 3 D D P 1$ & This study \\
\hline $\mathrm{p} 4919$ & YEpLac 195 & 2 micron URA3 URA6 & This study \\
\hline p4943 & YCplac111 & UBA1 CEN ARS LEU2 & This study \\
\hline p5183 & pFL44L & 2 micron URA3 ECM 21 & This study \\
\hline p5504 & YEpLac 195 & UBI4 2 micron $U R A 3$ & This study \\
\hline p5516 & YEpLac 181 & UBI4 2micron $L E U 2$ & This study \\
\hline p5791 & YEpLac 195 & CLB5 2 micron $U R A 3$ & This study \\
\hline
\end{tabular}


Fig. 1 Schematic representation of the de novo purine and histidine pathways (a) and the ubiquitin cascade (b) in yeast. a Only the enzymes mentioned in the text are shown (in green). AICAR: 5-Amino-Imidazole 4-CarboxAmide Ribonucleoside; AMP: adenosine 5'monophosphate; GMP: Guanosine 5'-monophosphate; IMP: Inosine 5'-monophosphate; PRPP: $\alpha$-D-ribofuranose 5-phosphate 1-diphosphate; ZMP: AICAR monophosphate. b E1, E2 and E3 stand for ubiquitin-activating enzyme, ubiquitin-conjugating enzymes and ubiquitinprotein ligases, respectively. Target: protein target. Ub: ubiquitin.

Fig. 2 AICAR toxicity in the hypomorphic ubal-ol mutant is alleviated by ubiquitin overexpression. a The adel6 ade17 ubal-ol is viable only if UBAl is ectopically expressed. Wild-type (BY4742) and mutant (ade16 ade17: Y1093; ubal-ol: Y6853; ade17 ubal-ol: Y7070; ade16 ubal-o1: Y7071 and ade16 ade17 ubal-o1: Y7117) strains containing a plasmid allowing expression of $U B A I$ gene under the control of a doxycycline-repressible promoter (p4515) were grown on SDcasaWA medium containing (+) or not (-) doxycycline (Dox;100 mg/l). b Growth of the ubal-ol mutant is impaired at semi-permissive temperature when ZMP is accumulated by exogenous addition of its riboside precursor AICAR in the ade8 ade16 ade17 hisl (Quad) genetic background. Strains (Y6987, Y2950 and Y8033) were grown for 48 hours at indicated temperatures on SDcasaWAU medium containing or not AICAR (10 mM). c Overexpression of gene-dosage suppressors restored growth of the ubalo1 mutant in the presence of AICAR. The ade8 ade16 ade17 his1 ubal-ol quintuple mutant was transformed with plasmids allowing overexpression of indicated genes (ECM21: p5183; URA6: p4919; DDP1: p4859; RPLAOB: p4807; RPL40A: p4814 and UBI4: p5504) or with an empty vector (YepLac195). Growth of transformants was scored for $72 \mathrm{~h}$ at $32^{\circ} \mathrm{C}$ on SDcasaWA medium in the presence or not of AICAR $(6 \mathrm{mM})$. d Free ubiquitin and ubiquitinconjugated signals were strongly increased when $U B I 4$ gene is overexpressed (OE). Strains (Y2950 and Y8033) were transformed with a plasmid allowing UBI4 overexpression (p5504) or the cognate empty vector (YEplac195). Total protein extracts were prepared from transformants, overexpressing (+) or not (-) UBI4, grown in SDcasaWA medium and treated (+) or not (-) for 2 hours with AICAR $(1 \mathrm{mM})$. Proteins were revealed by western blotting with anti-Ubi and anti-Act1 antibodies. Arrow points to free ubiquitin. Expo: Overexposure of 527 the dashed box region revealed with anti-Ubi antibody. 
Fig. 3 Mutants with low ubiquitin are highly sensitive to AICAR. a Conjugated ubiquitin is drastically decreased in $u b p 6$ and doal mutants. Total protein extracts were obtained from strains (Y2950 (Control), Y10296 and Y10696) grown in SDcasaWAU medium, separated by SDS-page and ubiquitin-conjugated proteins were revealed by western blotting with an antiubiquitin antibody. Act1 was used as a loading control. b Overexpression of UBI4 is sufficient to restore growth of the $u b p 6$ and doal mutants in the presence of AICAR. Yeast strains (Y2950 (Control), Y10696, Y10296 and Y9168) were transformed with plasmids allowing overexpression (OE) of either UBI4 (p5504) or CLN3 (p4742), or with the empty vector (none, YEpLac195). Transformants were grown at $37{ }^{\circ} \mathrm{C}$ for $48 \mathrm{~h}$ on SDcasaWA medium containing or not AICAR $(2 \mathrm{mM})$. c Ubiquitylation of H2B is increased when UBI4 is overexpressed (OE). Total protein extracts were obtained on transformants from Fig. $\mathbf{3 b}$. H2B pools were revealed by western blotting using an anti-H2B antibody. Act1 was used as a loading control. Quantifications were set at 1 for the control strain transformed with the empty vector (-). ND: not detectable.

Fig. 5 Gene-dosage suppression of AICAR-sensitivity of the $c d c 4-3$ and $c d c 34-2$ mutants. Yeast strains (Y8679 (a, d), Y8675 (b, c), Y9516 (e), Y9168 (f), Y10696 (g), Y10296 (h) and Y8033 (i)) were transformed with plasmids allowing overexpression (OE) of either CLB5 (p5791), CLN3 (p4742) or UBI4 (p5504) genes, or with an empty plasmid (YEpLac195, 
none). In all panels, transformants were grown on SDcasaWA medium containing or not AICAR at $30^{\circ} \mathrm{C}(\mathbf{b}) 32^{\circ} \mathrm{C}(\mathbf{c}, \mathbf{i}), 33^{\circ} \mathrm{C}(\mathbf{a}, \mathbf{d})$ or $37^{\circ} \mathrm{C}(\mathbf{e}-\mathbf{h})$.

Fig. 6 Schematic representation of the "ubiquitin sub-pathways" revealed by gene-dosage suppression of the AICAR-sensitivity. Mutant names in white-bold letters correspond to the AICAR-sensitive or -insensitive mutants characterized in this study.

Fig. 7 Combination of AICAR-sensitive mutants and gene dosage suppressors revealed complex genetic relationships between AICAR-sensitivity and ubiquitin pathways. a The double ubp6 bre1 mutant is hypersensitive to AICAR treatment. Yeast strains (Y10757, Y2950, Y9516 and Y10296) were transformed with the UBI4 overexpressing plasmid or the empty vector (none). Transformants were grown on SDcasaWA medium at $37^{\circ} \mathrm{C}$ for $48 \mathrm{~h}$. b Additive AICAR sensitivity was observed by combining setl and doal mutations. Strains (Y2950, Y10696, Y10524 and Y11389) were grown in SDcasaWAU medium for $72 \mathrm{~h}$ at $37^{\circ} \mathrm{C}$. (c) Double $C L N 3$ and $U B I 4$ overexpression is required to restore growth of the ade8 ade16 ade17 hisl ubal-ol in the presence of AICAR. Yeast strain (Y11352) was cotransformed with plasmids overexpressing or not (empty vectors) CLN3 and UBI4 genes. Transformants were grown for $72 \mathrm{~h}$ on SC medium lacking leucine and uracil. (d) The ubiquitylation-defect of $\mathrm{H} 2 \mathrm{~B}$ in the ade8 adel6 ade17 hisl ubal-ol is restored by UBI4 overexpression. Yeast strains (Y2950, Y8033 and Y9516) were transformed with a plasmid overexpressing UBI4 (+) or the cognate empty vector (-). Total protein extracts were obtained on transformants grown in SDcasaWA medium at $32{ }^{\circ} \mathrm{C}$ and treated $(+)$ or not (-) with AICAR (1 mM; 2 h). H2B and Act1 (loading control) were revealed by western blotting. Quantification was set at 1 for the control strain transformed with the empty vector (-). ND: not detectable. 
Fig. 1

a

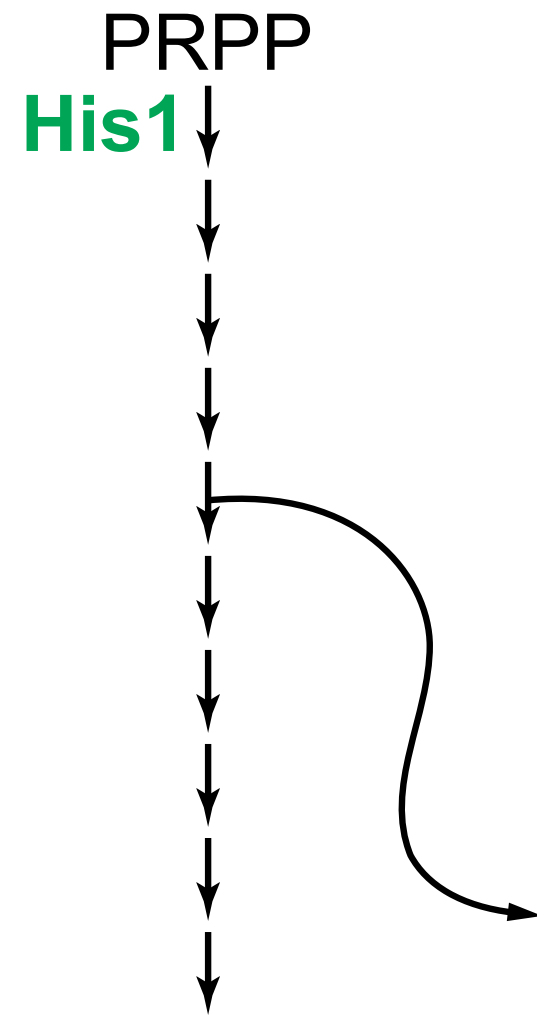

PRPP

His1 $\downarrow$

Histidine

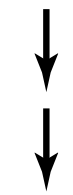

$\downarrow$ Ade8

$\downarrow$

$\downarrow$

$\downarrow$

$\downarrow$

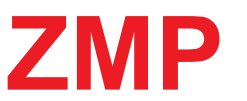

$\downarrow$ Ade16

$\downarrow$ Ade17

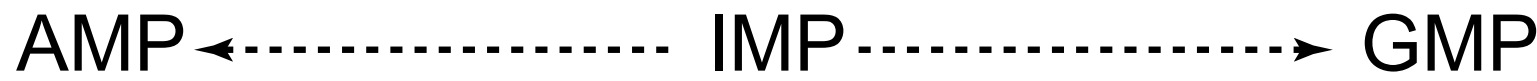

In

PM

Out

b

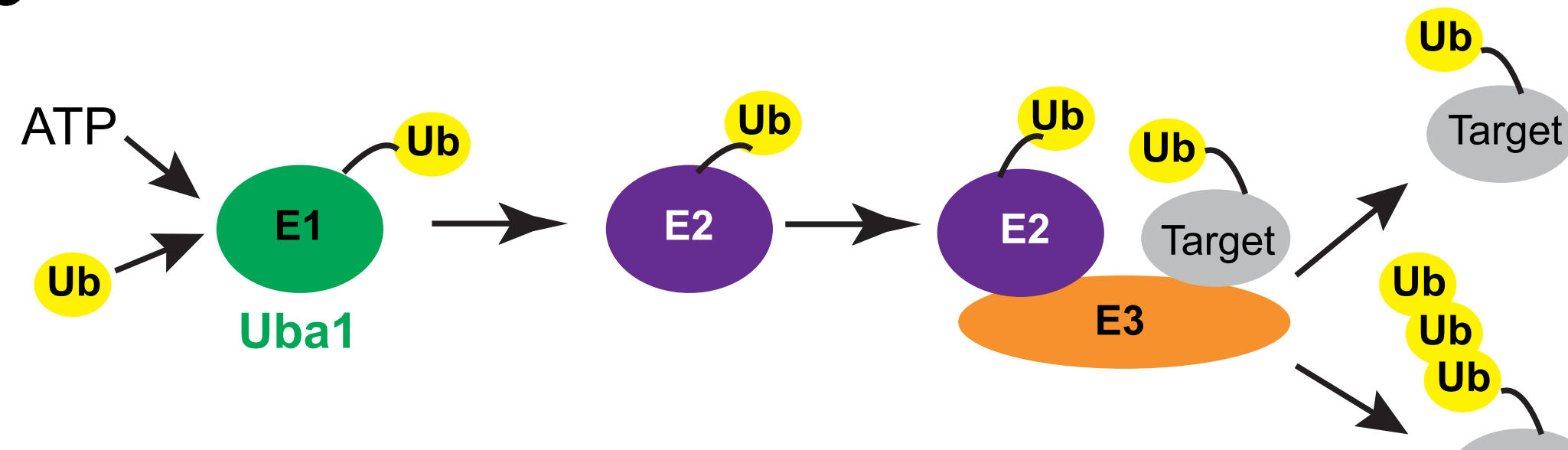

Target 
a

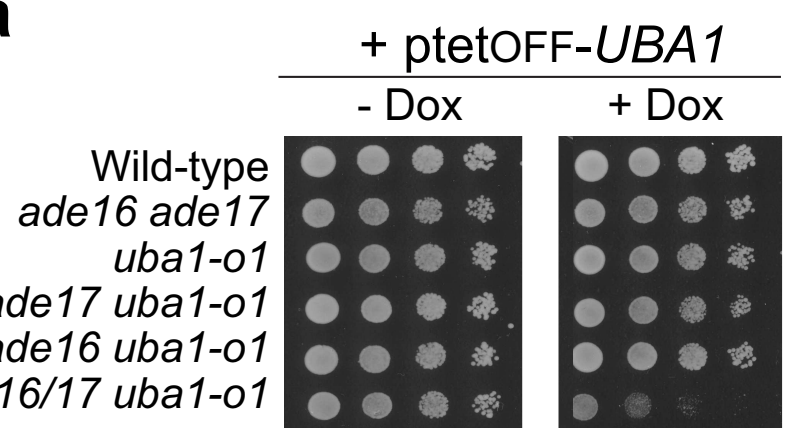

b

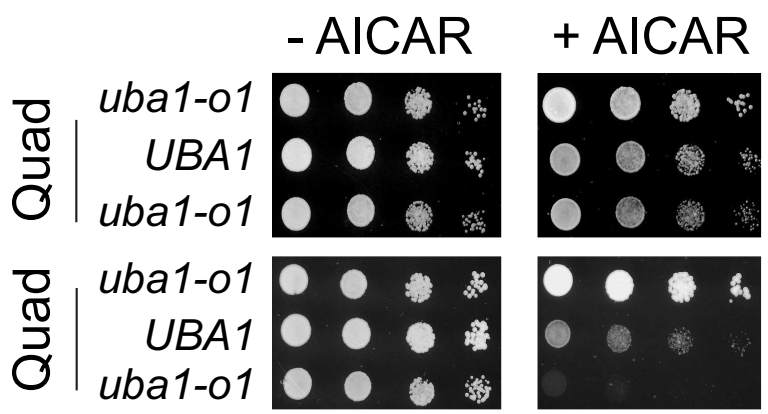

C

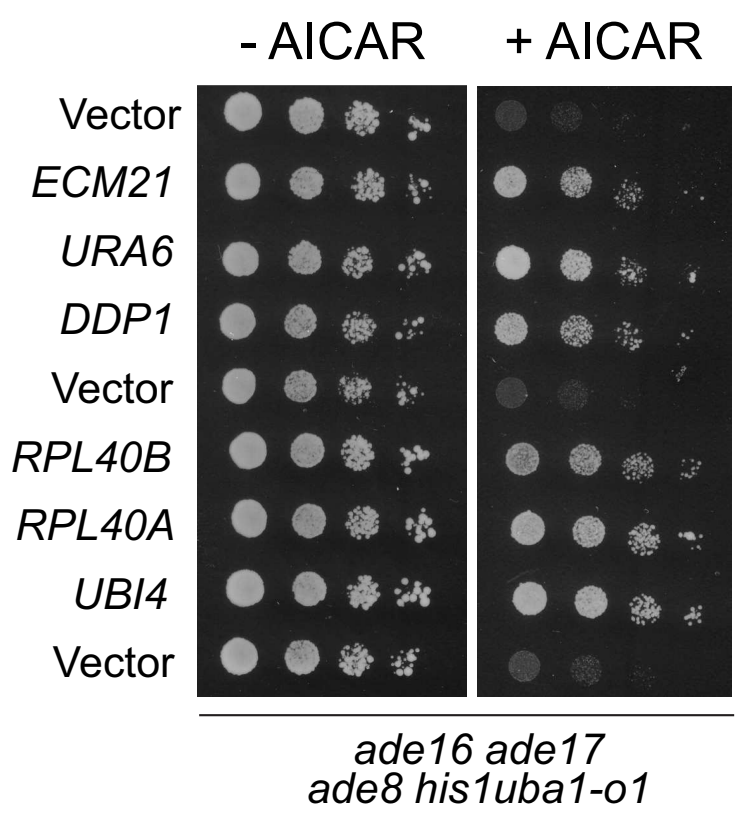

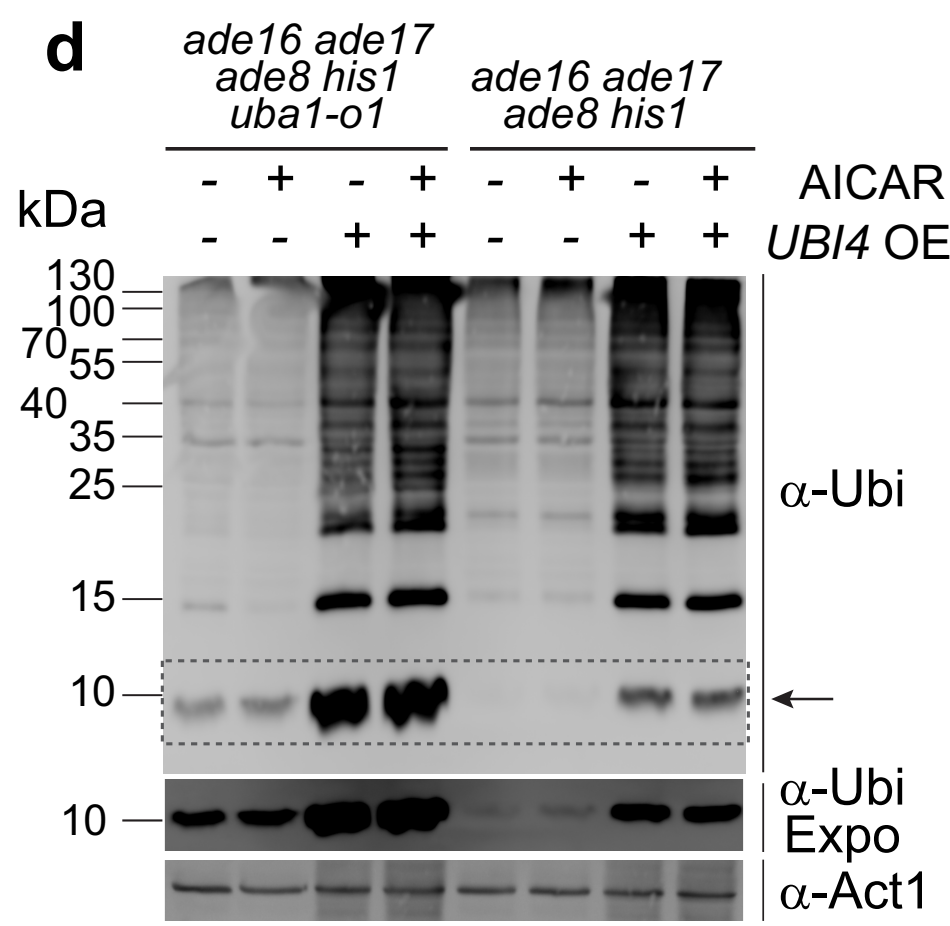


a

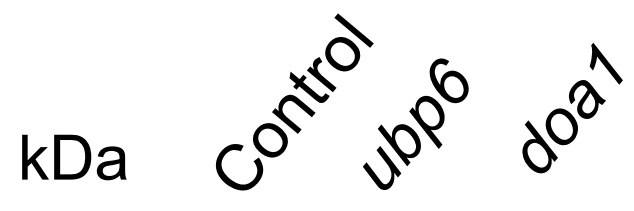

$170=$
$100=$
$70=$
$50=$
$35-$
$25-$

$15-$

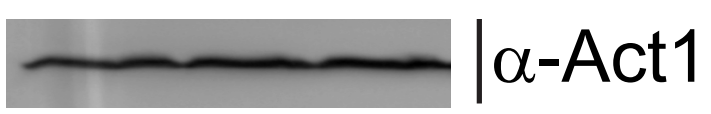

ade16 ade17

ade8 his1

$\alpha-U b i$ b OE gene - AICAR + AICAR

일

UBI4

None

CLN3

$000=$

:

$\therefore$

$00 \%$

$\stackrel{n}{\frac{\pi}{2}}$

\begin{tabular}{l|lll}
$\pi$ & UBI4 & 0 & 0 \\
$\frac{\pi}{8}$ & None & 0 & 0 \\
& CLN3 & 0 & 0
\end{tabular}

\begin{tabular}{l|l}
0 \\
$\frac{2}{3}$
\end{tabular}

UBI4

None

CLN3
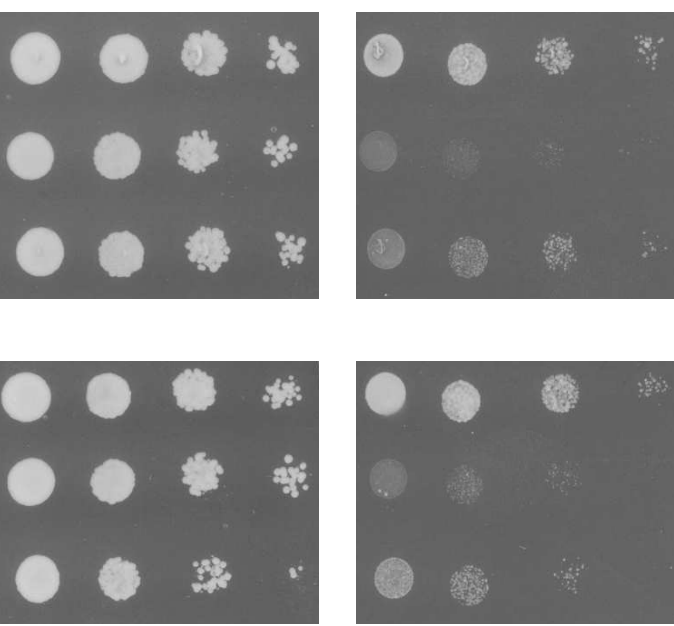

$\frac{1}{2}$

$U B / 4 \bigcirc O$ सं

None 0 is

CLN3OO

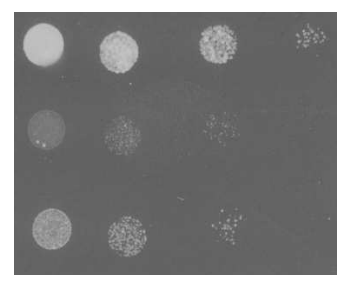

ade16 ade17 ade8 his1

UBI4 OE $\frac{\text { bre1 }}{-} \frac{\text { doa1 }}{-++} \frac{\text { Control }}{-++} \frac{\text { ubp6 }}{-+} \frac{\text { bre1 }}{-}$

$\mathrm{Ub}-\mathrm{H} 2 \mathrm{~B}>$

$\mathrm{H} 2 \mathrm{~B}>$

$\alpha-A c t 1>$

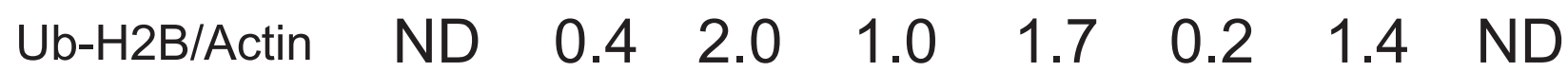




\section{AICAR-sensitive mutants}

Suppressed by

CLN3 overexpression

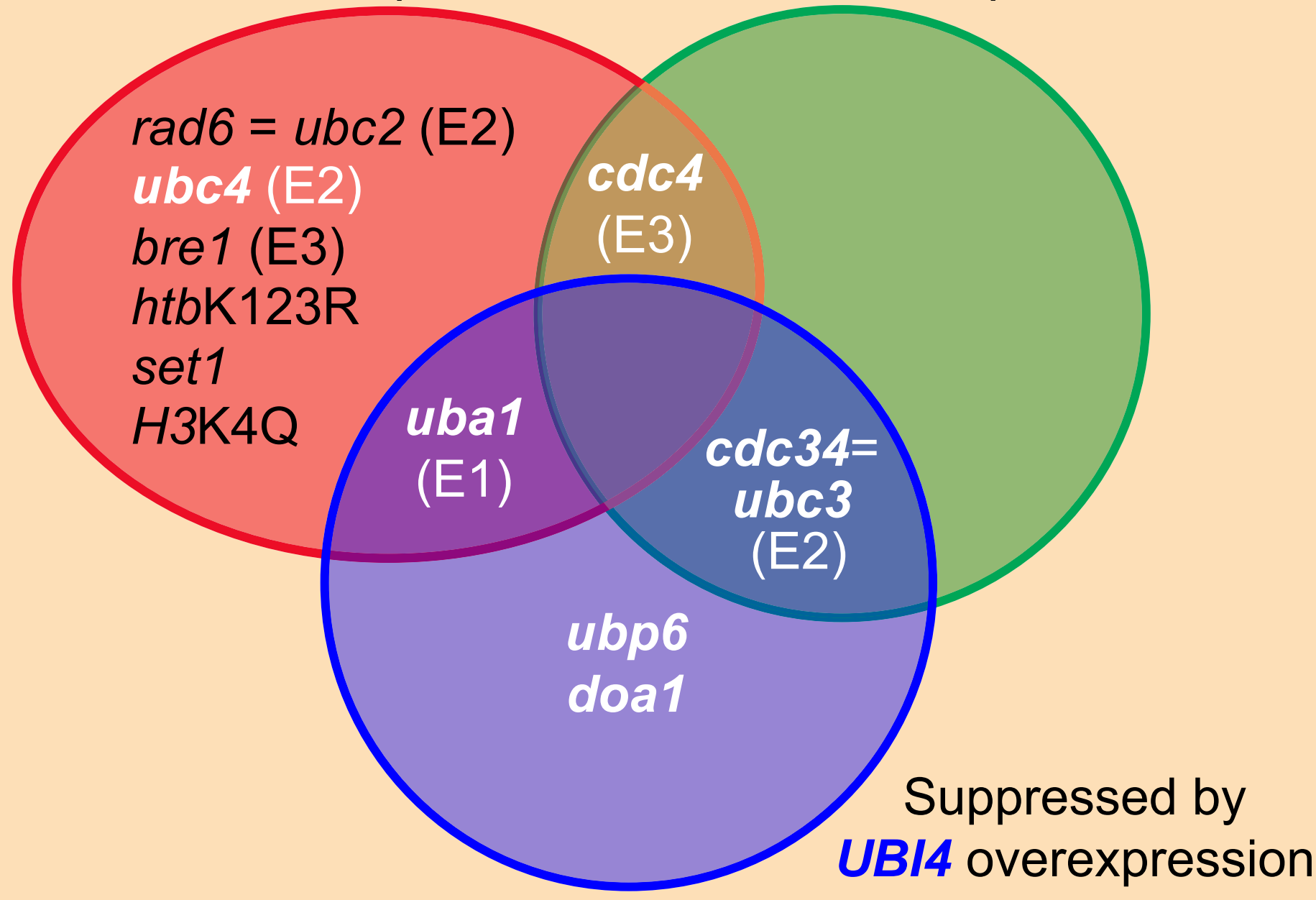

Suppressed by

CLB5 overexpression

\section{AICAR- insensitive mutants}

ubc1 (E2)

ubc5 (E2)

ubc6 (E2)

ubc7 (E2)

ubc8 (E2)

ubc10 (E2)

ubc11 (E2)

ubc13 (E2) 
a

gene

$\begin{array}{lll}\text { No } \\ 0 & 0 & 0 \\ 0 & 0 & 0 \\ 0 & 0 & 0 \\ 0 & 0 & 0\end{array}$

bre1 $\begin{aligned} & \text { None } \\ & \text { UBI4 }\end{aligned}$

ubp6 $\mid$ None

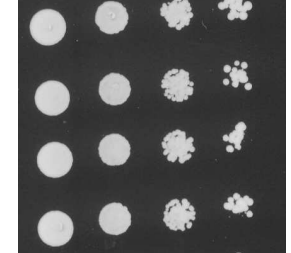

ade16 ade17 ade8 his1

b

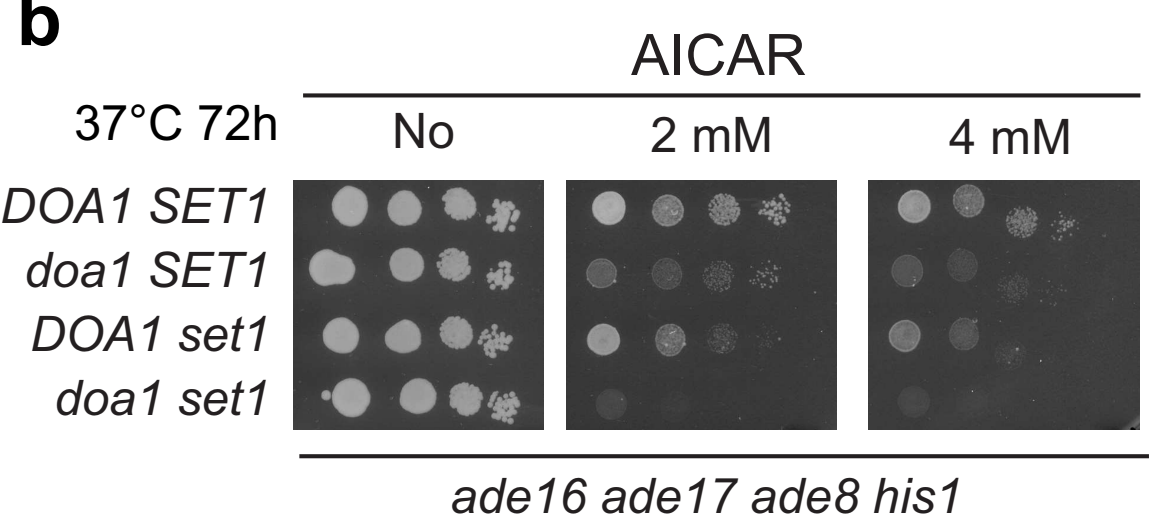

AICAR

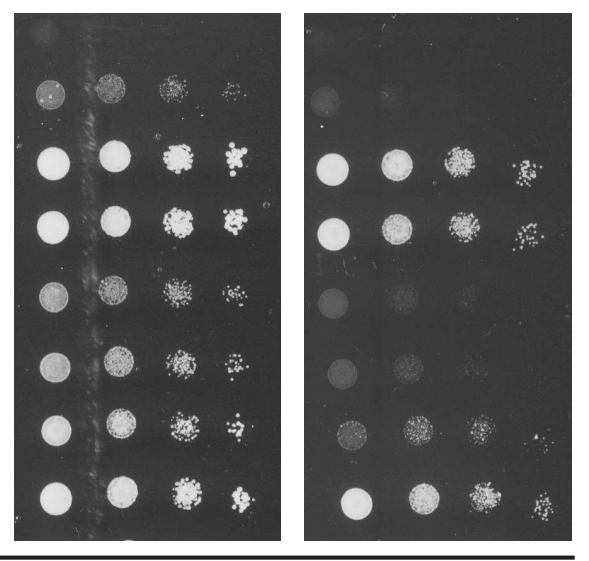

$C L N 3+U B / 4$

CLN3

None

UBA1

None

UBI4

$C L N 3+U B / 4$

CLN3

None

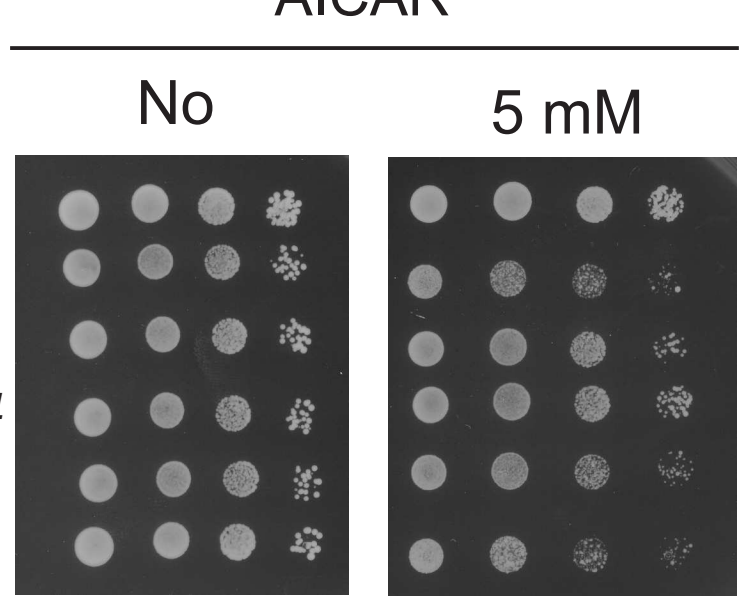

$30^{\circ} \mathrm{C}$

$32^{\circ} \mathrm{C}$

d

ade16 ade 17 ade 8 his 1

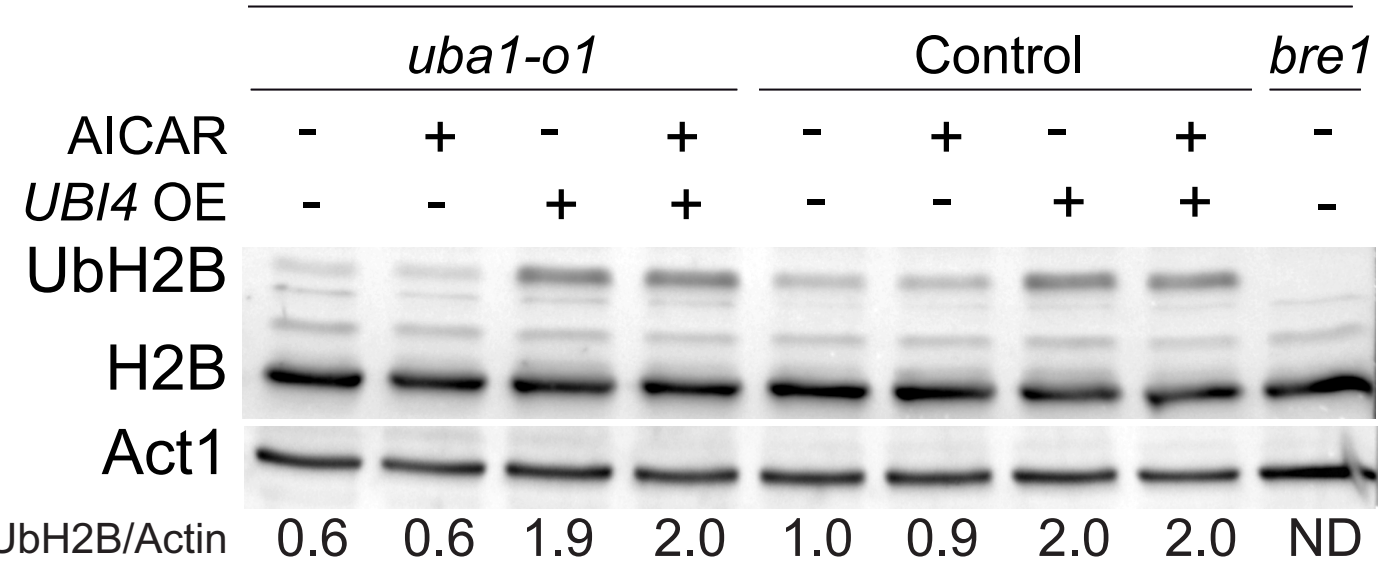

